\title{
TOWARDS A DASHBOARD OF SUSTAINABILITY INDICATORS FOR PANAMA: A PARTICIPATORY APPROACH
}

\author{
Anthony Sardain, Cécile Tang, Catherine Potvin \\ Department of Biology, McGill University, 1205 Docteur Penfield, Montréal H3A1B1, Québec, Canada
}

\begin{abstract}
:
The importance of pursuing sustainable modes of development has received increased global recognition in recent years. Since the issue was first addressed in the United Nations' 1987 Brundtland Report, many countries have developed their own sustainability strategies. In Panama, a UNESCO Chair entitled Dialogues on Sustainability was created in 2011 by four scholarly institutions with the objective of advancing a sustainability agenda through education, research and discussion. In line with conclusions from the United Nations' Agenda 21 action plan, the UNESCO Chair identified the creation of a set of national sustainability indicators as an important step toward this goal. This paper presents the work done by the Chair to develop a dashboard of national sustainability indicators for Panama. Indicators were selected using participatory methods, involving 42 individuals representing 16 different government agencies, NGOs, academic institutions, and private entities from Panama. Adhering to a three-pillar structure, the resulting dashboard of 20 indicators is shown to be a useful tool for understanding past trends, present issues, and future trajectories within Panama's economic, environmental, and social spheres. As a further demonstration of the dashboard's utility, this paper focuses on three example issues shown by the dashboard to be important: security, vehicles and vehicle emissions, and natural disasters. This paper also juxtaposes the Human Development Index and Ecological Footprint to compare Panama with other Latin American countries.
\end{abstract}

Keywords: Sustainability, indicator, participatory, environmental, socio-economic, Panama

\section{Introduction}

In the face of growing environmental change and awareness, increasing international attention has been paid to modes of development that are sustainable over time and space. The United Nations' (UN)

Brundtland Report spearheaded contemporary discussions of sustainability by calling for "development that meets the needs of the present without compromising the ability of future generations to meet their own needs" (World Commission on Environment and Development, 1987). Indeed, the UN's action plan Agenda 21, produced during the 1992 Earth Summit and built off of the Brundtland Report, identified the establishment of a green economy and sustainable development as urgent international priorities (UN, 1992; Spangenberg et al., 2002). The importance of sustainability was reaffirmed at the Rio+20 conference in 2012 and is central to the post-2015 Sustainable Development Goals agenda (UN General Assembly, 2015).

Finding ways to measure sustainability was identified in Agenda 21 as one of the principal objectives for nations (UN, 1992). Yet, over twenty years later, how best to measure progress towards sustainability remains a subject of debate. One approach is to use composite indices (Nardo et al., 2005). The composite index utilizes multiple indicators as input and produces a single, aggregated value as output (Nardo et al., 2005). The Ecological Footprint (EF), which measures the amount of biologically productive land required to sustain a given population's consumption patterns, is an index of environmental sustainability (Ewing et al., 2010). Composite indices have numerous advantages: they allow for 
summarizing multi-dimensional realities, are easy to grasp conceptually, and, consequently, tend to be effective for communicating with the general public (Nardo et al., 2005). However, aggregating indicators inevitably results in a loss of information and introduces subjectivity through relative weighting of the index's components (Reed et al., 2006). Moreover, composite indices lend themselves to a weak sustainability paradigm, whereby decline in one sector can be compensated by growth in another, as aggregation necessarily allows for degrees of substitutability and compensability (Stiglitz et al., 2010). Such substitutions have been criticized for i) the uncertainty that substitution is truly possible, ii) the irreversibility of some forms of environmental damage, and iii) the necessity to maintain most natural resources above critical levels to support life and maintain environmental resilience (Ekins et al., 2003; Stiglitz et al., 2010).

Related to composite indices are methods that alter national accounts to incorporate elements relevant to sustainability. Efforts to "green" the Gross Domestic Product (GDP) are an example of this, whereby deductions are introduced to a country's GDP to account for damage to or depletion of natural resources (Stiglitz et al., 2010). These methods are similar to composite indices in that they produce a single aggregated output value, in this case monetary. These methods face many challenges, however, notably assigning costs to environmental degradation, which can be difficult to quantify (Heal, 2012). Furthermore, the use of aggregation in these methods means they too are inherently weak sustainability measures.

Another approach is to present a certain number of indicators in a set order, known as a dashboard of indicators. The advantage of this method is that specificity and precision are retained. Further, by keeping indicators separate and non-aggregated, this method lends itself more easily to a strong sustainability policy (Stiglitz et al., 2010). However, this gain comes at the cost of ease of use. Dashboards can appear to deliver a lot of information at once, and can seem heterogeneous and un-harmonized, which may complicate interpretation (Stiglitz et al., 2010). To prevent this, indicators can be grouped according to different schemes, such as common themes or policy objectives.

Methods for choosing sustainability indicators are equally diverse (see Bell \& Morse, 2003). Recent years have seen a growing focus on participatory methods applied to indicator selection in many countries (eg. Maxim, 2012). Participatory methods seek to bring the stakeholders - those whom the indicators are supposed to serve - into the indicator selection process. This "bottom-up" approach aims to balance what has traditionally been a "top-down", expert-led process (Reed et al., 2006). Top-down, expert-led approaches have the advantage of benefitting from greater technical knowledge; however, in failing to involve a wider community of stakeholders, they lose a potentially important source of knowledge of the local context (Reed et al. 2006). Additionally, failing to involve stakeholders may result in the indicators lacking legitimacy in the eyes of the stakeholders (Chamaret et al., 2007), potentially compromising the adoption of the indicators. In order to balance the strengths and weaknesses of each method, some participatory efforts have sought to incorporate elements of both expert-led and stakeholder-led approaches to indicator selection (Chamaret et al., 2007).

Despite this diversity in methods, many countries have adopted similar approaches when developing sustainability indicators. Following an investigation of 34 such initiatives, spanning 19 countries, Côté \& McCollough (2007) identified numerous common elements between efforts. First, most initiatives used advisory and participatory methods to facilitate cooperation and discussion of sustainability indicators, while prioritizing broad consultation of various stakeholder groups and consensus. Second, many institutions favored using fewer indicators to combat information overload and facilitate comprehension. Third, there was a strong preference for selecting indicators that use previously existing data over compiling a list of 'ideal' indicators and then pushing for data collection. Fourth, most initiatives categorized their sustainability indicators by domain or by "pillar". The term "pillar" refers to one of three dimensions - economic, environmental, and social sustainability - that, together, are commonly held to be the foundation of sustainable development.

The present paper presents work done in Panama to develop a dashboard of sustainability indicators that could assist in understanding the rapid changes occurring in the country. Indeed, Panama is currently experiencing a period of rapid economic growth: according to World Bank estimates, Panama's GDP grew by nearly $11 \%$ in 2011 and 2012, and by $8.5 \%$ in 2013, which was the second highest increase in Latin America for that year (http://data.worldbank.org/country/panama). The question of interest is whether this high economic growth is bringing social and environmental benefits - thus advancing the sustainability agenda - or whether it fosters social inequality and environmental degradation. A dashboard 
of sustainability indicators was developed using participatory methods, taking elements from both topdown and bottom-up strategies.

\section{Methods}

\subsection{Institutional Context}

A UNESCO Chair entitled Dialogues on Sustainability was created in 2011 in Panama by four scholarly institutions: McGill University, the Smithsonian Tropical Research Institute (STRI, located in Panama), the Institute of Scientific Investigations and Services of High Technology (INDICASAT), the Catholic University Santa María la Antigua (USMA), with C.P. being the Chair Holder. An inaugural meeting on August $3^{\text {rd }} 2012$ in Panama City was attended by seventy-one participants from varying sectors: private, NGO, government, indigenous, academic. Attendees emphasized the need for "continuity and stability to existing efforts to ensure the sustainability of socio-ecosystems, and to create a space for dialogue about research topics on sustainability and generate constructive ideas and proposals based on rigorous analysis" (Foro y Observatorio de Sostenibilidad, 2012). With this mission, the UNESCO Chair created a Forum and Observatory for Sustainability (henceforth FOS;

http://usmapanama.com/foroyobservatoriodesostenibilidad/es). One of the priorities identified during the inaugural meeting was the development of a national dashboard of sustainability indicators. These indicators would need to be implementable immediately and should track changes in real time. The FOS designated the authors of this study to organize and conduct the dashboard development process.

To accomplish this objective we used the "focus-group technique", which seeks to "stimulate dialogue between participants in a small group on a specific theme, encouraged by a moderator" (Chamaret et al., 2007). The purpose of the focus group was to carry out the indicator selection process. A maximum diversity in stakeholder participation was sought out for the focus group. Consequently, the number of participants was kept large enough to include a diversity of perspectives but small enough to ensure the group remained functional and direct. Invitations to join the focus group were extended to relevant government agencies and NGOs that worked with indicators as part of their occupation. Thus the focus group constituted the top-down, expert-led element in our top-down/bottom-up participatory approach.

The work of the focus group was complemented and validated by a workshop to capture a larger sample of perspectives, opinions, and interests, which constituted the bottom-up, stakeholder-led element. Persons invited to participate in the workshop were selected among researchers, managers, and representatives of projects pertaining to sustainability, although not necessarily to indicators. All invited persons were identified from STRI contacts and from participants of the August 2012 FOS meeting. Invitations were sent by e-mail. We invited 94 persons - representing 14 governmental agencies, 13 NGOs, 4 academic institutions, and 3 private entities - to participate in the workshop, of which 32 ultimately participated (Table 1). Of the 94 persons invited to participate in the workshop, 22 were also invited to participate in the focus group. Of these 22, 20 participated in at least one focus group meeting. In total, 42 persons participated in the focus group and/or the workshop. For a full list of the groups in attendance, refer to Supplementary Material.

Table 1. Number of participants in the indicator selection process by affiliation. Numbers of participants in focus group and workshop may not sum to total as some individuals participated in both groups. For focus group, counts represent individuals that attended at least one of the two meetings.

\begin{tabular}{lccc} 
& Focus group & Workshop & Total \\
\hline NGO & 5 & 5 & 8 \\
Governmental & 14 & 14 & 23 \\
Academic & 0 & 9 & 9 \\
Private & 1 & 2 & 2
\end{tabular}

\subsection{Indicator selection}

\subsubsection{Step One: Preliminary list of candidate indicators}


A literature review helped identify key desirable qualities of sustainability measures: (1) a good indicator must be clear (Niemeijer \& de Groot, 2008), scientifically rigorous (Spangenberg et al., 2002), and as objective as possible (Bossel, 1999). This criterion allows for the establishment of points of comparison and reference, threshold values, and objectives (Liverman et al., 1988; Hall, 2001). (2) A good indicator must be pertinent (Duinker, 2001) and reliable (Miller, 2000). One must be certain that the information conveyed by the indicator represents what it is ultimately trying to measure (Braat, 1991). (3) A good indicator must be based on accurate, accessible information (Liverman et al., 1988). For this reason, using existing indicator data is favorable as the creation of a new indicator may incur significant financial costs (Crabtree and Bayfield, 1998). Indicators that make use of poor data risk introducing error (Duinker, 2001). Meanwhile, good long-term data can be used to establish trends (Liverman et al., 1988) and evaluate effectiveness of policy measures (Verbruggen \& Kuik, 1991). (4) A good indicator must be easily applied and understandable (Bradley Guy \& Kibert, 1998). Although indicators are often developed by experts, use and interpretation of an indicator must be clear even to laypeople (Bradley Guy et al., 1998), including the general public and potential decision-makers. However, this condition should not be an impediment to scientific rigor by oversimplifying (Bossel, 1999). These four criteria were applied when identifying indicators for the selection process in our study.

Indicator selection was undertaken through a series of meetings and web surveys, which took place in Panama City between January and July 2013. A first meeting with the focus group included 17 participants from NGO, governmental and private sectors and served to develop a work plan and compile available indicators. Participants were asked to provide the list of environmental sustainability indicators used by his/her institution and these were compiled into an exhaustive list of 341 indicators. Four institutions brought indicators: Autoridad del Canal de Panamá (ACP), Autoridad Nacional del Ambiente (ANAM; now Ministerio de Ambiente, MiAmbiente), Ministerio de Vivienda (MIVIOT), and Ministerio de Desarrollo Agropecuario (MIDA). The focus group participants discussed the indicators of the exhaustive list and criteria for inclusion in a preliminary list of candidate indicators, from which the final dashboard of indicators would eventually be chosen. In addition to conforming to the four criteria of a good indicator stated above, focus group participants requested that indicators make use of data reported with a periodicity of at most three years. Those indicators that satisfied all the stated criteria were compiled into the preliminary list of 186 candidate indicators.

\subsubsection{Step Two: Revised list of candidate indicators}

Input on the preliminary list of candidate indicators was received during an open workshop. At the beginning of the workshop, to establish a common ground of discussion, two presentations were made. The first clarified different sustainability concepts, while the second outlined the rationale behind the development of indicators for Panama, explained the methodology proposed for indicators selection, and presented an overview of criteria of good indicators as per the literature review. After the presentations, participants were asked to join one of two discussion groups, one focusing on urban sustainability and the other open to general sustainability issues. In each discussion group, participants were presented with the preliminary list of candidate indicators and, under the supervision of a moderator, identified important sustainability issues and potential indicators of interest for the final dashboard of indicators. Consensus emerged from the workshop: (1) adoption of a dashboard of indicators was favored over the selection of specific indices; (2) the dashboard should include indicators of economic, environmental, and social sustainability, hereafter referred to as the three pillars of sustainability; (3) the preliminary list of candidate indicators did not address a number of important sustainability themes. We recorded those themes that participants felt were not addressed by the preliminary list of indicators.

To obtain indicators that address the sustainability themes identified during the workshop, we conducted an extensive survey of all national indicators collected by Contraloría General de la Republica de Panamá (hereafter Contraloría). Contraloría manages national statistics and indicators. All indicators that addressed the sustainability themes identified during the workshop and met the requirements for inclusion were added to the preliminary list of candidate indicators. The resulting list of 247 candidate indicators was circulated by email to all 94 individuals invited to participate in the workshop and/or the focus group. These individuals were asked to select the 5 most important indicators for each pillar of sustainability. We received only 15 responses from this web survey. All indicators mentioned in the responses were included in the revised list of indicators of 70 indicators. 


\subsubsection{Step Three: Final list of indicators}

To select a final list of indicators the focus group was invited to meet and presented with the revised list of indicators. Of the 22 persons invited, 11 participated in this second focus group meeting.

Participants discussed each indicator at length until consensus to include or exclude it was reached. Once a list of indicators was settled, the focus group asked the research team to (1) identify a few additional indicators of social and environmental sustainability and seek later feedback with them by email and (2) examine the pattern of correlations amongst indicators within and between pillars. Complementary to the dashboard of indicators, the focus group also decided to use Panama's Human Development Index (HDI) and EF to compare Panama to other Latin American countries (Messina, 2012). We defined Latin America as all Central and South American countries where Spanish or Portuguese are official languages.

The HDI, a unit-less index of socio-economic well-being, aggregates indicators of education, health, and income, and can have a value between 0 and 1 (Malik, 2014). The EF, an index of environmental sustainability, is expressed in "global hectares" and compares the amount of biologically productive area necessary to sustain a nation's population (a nation's "footprint") with the total biologically productive area globally available (the earth's "biocapacity") (Ewing et al., 2010). Consistent with other studies comparing HDIs and EFs of nations (Moran et al., 2008; Neumayer, 2012), we defined the sustainability objective of nations to have an EF within the limits of the earth's biocapacity (1.78 global hectares per capita) (Ewing et al., 2010), and an HDI $\geq 0.8$, which is the threshold of "very high development" as defined by the UN Development Programme (UNDP) (Malik, 2014).

\subsection{Data compilation and correlations}

Data was obtained from Contraloría (http://www.contraloria.gob.pa/inec/

Publicaciones/Default.aspx) for all of the indicators on the final list, except where otherwise indicated (Table 2). Annual values for each indicator were compiled, going back to 1990 or more recent, depending on data availability. Most values are published with some delay, such that the most recent data available for indicators ranged from 2011 to 2013. GDP data, for instance, is available until 2011, inclusive, as Contraloría is currently recalculating data in base 2007 prices. Preliminary values for indicators were excluded during data compilation, and in cases where Contraloría retroactively recalculated values for indicators and published them as revised values these revised values were used.

HDI data was obtained from the UNDP's Human Development Report 2014 (Malik, 2014). EF data was obtained from the Ecological Footprint Atlas 2010 (Ewing et al., 2010). Both datasets were the most recent ones available at the time of publication.

Pearson's product-moment correlation coefficients were first calculated between indicators within each pillar of sustainability (i.e. economic, environmental, social). These correlations served as evidence of redundancy across indicators; redundant indicators might then be excluded from the final list. Pearson's product moment correlation coefficient was also calculated between indicators across pillars. This analysis served to identify components of sustainability not captured solely by economic indicators. For both intraand inter-pillar analyses, correlations were only calculated between indicators with clear causal links. All indicators for which correlations were calculated had at least 10 years of overlapping data. Significance of correlations was determined by a permutation test of 1000 permutations with replacement using the $\mathrm{R}$ package corPerm.R (Legendre, 2005). All statistical analyses were completed using R version 3.1.2.

Table 2. Final list of sustainability indicators as selected by the focus group. Indicators highlighted in grey were removed following correlation analysis. Data obtained from Contraloría except where otherwise indicated. 
ECONOMIC

Energy efficiency: Measured as total energy production in kilowatt-hours in the Republic of Panama divided by GDP per capita at purchaser's prices in Balboas at 1996 prices.

Foreign investment: Total value of holdings in the Republic of Panama by foreign investors in millions of Balboas.

GDP per capita: GDP per capita at purchaser's prices in Balboas at 1996 prices in the Republic of Panama.

GDP \% - Agriculture, livestock, hunting, forestry: Percent of GDP accounted for by agriculture, livestock, hunting and forestry sector.

GDP \%-Mining and quarrying: Percent of GDP accounted for by mining and quarrying sector.

\section{ENVIRONMENTAL}

$\mathrm{Km}^{2}$ of protected area per park ranger: Total area of designated protected areas per park ranger in the Republic of Panama.

Nitrogen oxide in Panama City: Mean atmospheric concentration of nitrogen oxides in Panama City. Data obtained from Instituto Especializado de Análisis at Universidad de Panamá and from Contraloría.

Number of sites monitored for water quality: Number of river sites monitored for water quality by ANAM (now MiAmbiente) in the Republic of Panama. Data obtained from ANAM.

Percent of rivers unpolluted: Percent of rivers monitored during dry season by ANAM (now MiAmbiente) in the Republic of Panama classified as "unpolluted" or "acceptably polluted" by ANAM. Data obtained from ANAM.

Total designated protected area: Total area of designated protected areas in the Republic of Panama. Vehicles per capita: Total number vehicles per capita in the Republic of Panama. Population data obtained from World Bank.

Waste production per capita: Annual disposal of solid waste in Cerro Patacón landfill, Panama City. Population was determined for districts of Panamá and San Miguelito, the two districts whose waste goes to Cerro Patacón. Population values for each district were obtained from Contraloría census data for 2000 and 2010, with intermediate and post-2010 values calculated using relative (exponential) growth rate based on the two census values.

Water consumption per capita: Total annual consumption of potable water per capita in thousands of gallons. Population data obtained from World Bank.

\section{SOCIAL}

Gini coefficient: Gini coefficient for the Republic of Panama. The GINI index measures equality of income distribution in a country, with 0 representing perfect equality and 100 representing perfect inequality. Data obtained from World Bank.

Infant mortality: Infant mortality within the first year. Calculated as number of deaths within the first year of life for every 1000 live births.

Investment in education: Public sector budget allocated to education per student in the Republic of Panama in thousands of Balboas.

Murder rate: Number of intentional homicides per 100,000 individuals. Data on number of homicides obtained from United Nations Office on Drugs and Crime. Data on population obtained from World Bank.

Number of dwellings affected per year by natural disasters: Total number of individuals affected by natural disasters in the Republic of Panama.

Number of individuals affected per year by natural disasters: Total number of individuals affected by natural disasters in the Republic of Panama. Includes persons affected, wounded and killed by a natural disaster, annually.

Number of individuals detained: Total number of individuals detained annually in the Republic of Panama. 
Number of minors detained: Total number of minors detained annually in the Republic of Panama.

Poverty rate: Percent of population in the Republic of Panama living on less than $\$ 2$ a day at 2005 international prices, annually. Data obtained from World Bank.

\section{Results}

\subsection{Selecting indicators}

Of the 70 indicators from the revised list of indicators, 19 were economic, 23 were environmental, and 28 were social. Of these, the focus group retained 23 indicators for the final list of indicators, of which 3 were removed following correlation analysis (Table 2). The final list contains 20 indicators -5 economic, 8 environmental, and 7 social. Of the 20 final indicators 2 indicators have between 5 and 9 years of data (inclusive); 9 indicators have between 10 and 14 years of data; and 9 indicators have 15 or more years of data.

\subsubsection{Dashboard of Indicators}

\section{Economic}

Pearson's correlation coefficient indicates that GDP per capita is significantly correlated with all other economic indicators (Table 3a). The correlation is positive with foreign investments and the proportion of GDP attributable to mining and quarrying. The correlation with GDP is negative for the proportion of GDP attributable to agriculture, livestock, hunting, and forestry.

Between 1996 and 2011, most of Panama's economic indicators show a constant upward trend (Figure 1a). GDP per capita, at 1996 prices, was $\$ 3312.14$ in 1996 and rose to $\$ 6222.66$ in 2011, an $81.87 \%$ increase. The indicator showing the largest increase is the proportion of GDP attributable to mining and quarrying, which grew fivefold from $0.3 \%$ in 1996 to $1.5 \%$ in 2011 . Foreign investment follows with a $231.35 \%$ increase, from $\$ 6260.02 \mathrm{M}$ in 1998 to $\$ 23,812.36 \mathrm{M}$ in 2011 . Meanwhile, energy efficiency decreased $15.54 \%$ between 1998 and 2011, from $0.39114 \mathrm{kWh} / \$$ GDP to $0.33036 \mathrm{kWh} / \$$ GDP. The percent of GDP attributable to agriculture, livestock, hunting, and forestry decreased $47.37 \%$, from $5.7 \%$ in 1996 to $3 \%$ in 2011.

Table 3. Pearson's correlations separated by pillar. (a) compares GDP per capita with other indicators from the final list of indicators; (b) presents all other inter- and intra-pillar correlations. Table only includes correlations between pairs of indicators that could be causally related. * significant at $\mathrm{p}<0.05$; ** significant at $\mathrm{p}<0.01$. 
a)

\begin{tabular}{|c|c|}
\hline & GDP per capita \\
\hline Foreign investment & $0.9966451^{* *}$ \\
\hline GDP $\%$ Agriculture & $-0.9566395^{\star \star}$ \\
\hline GDP \% Mining, quarrying & $0.9297718^{\star *}$ \\
\hline GDP \% Hotels, restaurants & $0.9796403^{* *}$ \\
\hline Detained individuals & $0.8116104^{* \star}$ \\
\hline Detained minors & $0.8239252^{* *}$ \\
\hline Gini coefficient & $-0.9371959^{* \star}$ \\
\hline Infant mortality & $-0.8464165^{\star *}$ \\
\hline Investment in education per student & $0.9882352^{* *}$ \\
\hline Murder rate & $0.9030285^{* *}$ \\
\hline Poverty rate & $-0.9701729^{* *}$ \\
\hline Nitrogen oxide concentration & -0.0744457 \\
\hline Vehicles per capita & $0.9698694^{* *}$ \\
\hline Waste production per capita & $0.9418324^{* *}$ \\
\hline Water consumption & $0.9268205^{* *}$ \\
\hline
\end{tabular}

b)

\begin{tabular}{|c|c|c|c|c|c|c|}
\hline & $\begin{array}{l}\text { Nitrogen oxide } \\
\text { concentration }\end{array}$ & $\begin{array}{c}\text { Detained } \\
\text { individuals }\end{array}$ & $\begin{array}{c}\text { Detained } \\
\text { minors }\end{array}$ & Gini coefficient & $\begin{array}{c}\text { Individuals } \\
\text { affected by } \\
\text { natural disasters }\end{array}$ & Poverty rate \\
\hline Vehicles per capita & -0.0496258 & -- & -- & -- & -- & -- \\
\hline Detained individuals & -- & 1 & 0.2640930 & $-0.8533316^{\star *}$ & -- & $-0.8442487^{\star *}$ \\
\hline Detained minors & -- & 0.2640930 & 1 & $-0.6579026^{*}$ & -- & $-0.6964985^{\star \star}$ \\
\hline Gini coefficient & -- & $-0.8533316^{* *}$ & $-0.6579026^{*}$ & 1 & -- & $0.9521702^{\star \star}$ \\
\hline Homes affected by natural disasters & -- & -- & -- & -- & $0.9268681^{* *}$ & -- \\
\hline Infant mortality & -- & -- & -- & $0.8625265^{\star *}$ & -- & $0.8587139^{\star \star}$ \\
\hline Investment in education per student & -- & $0.7485274^{* *}$ & $0.8645779^{* *}$ & $-0.8822913^{\star *}$ & -- & $-0.9499368^{* *}$ \\
\hline Murder rate & -- & $0.8194508^{* *}$ & $0.5468383^{*}$ & $-0.8306753^{* \star}$ & -- & $-0.9416898^{\star *}$ \\
\hline
\end{tabular}

Fig 1. Trajectories for economic (a), environmental (b), and social (c) indicators from final list of indicators after removal of redundant indicators. Y axis values represent annual data for each indicator as a ratio of first recorded value. Ratios have been log-transformed to contain the large variation in ratios across indicators. Thus, positive y values indicate the value of the indicator has increased since the first year, while negative y values indicate it has decreased. 

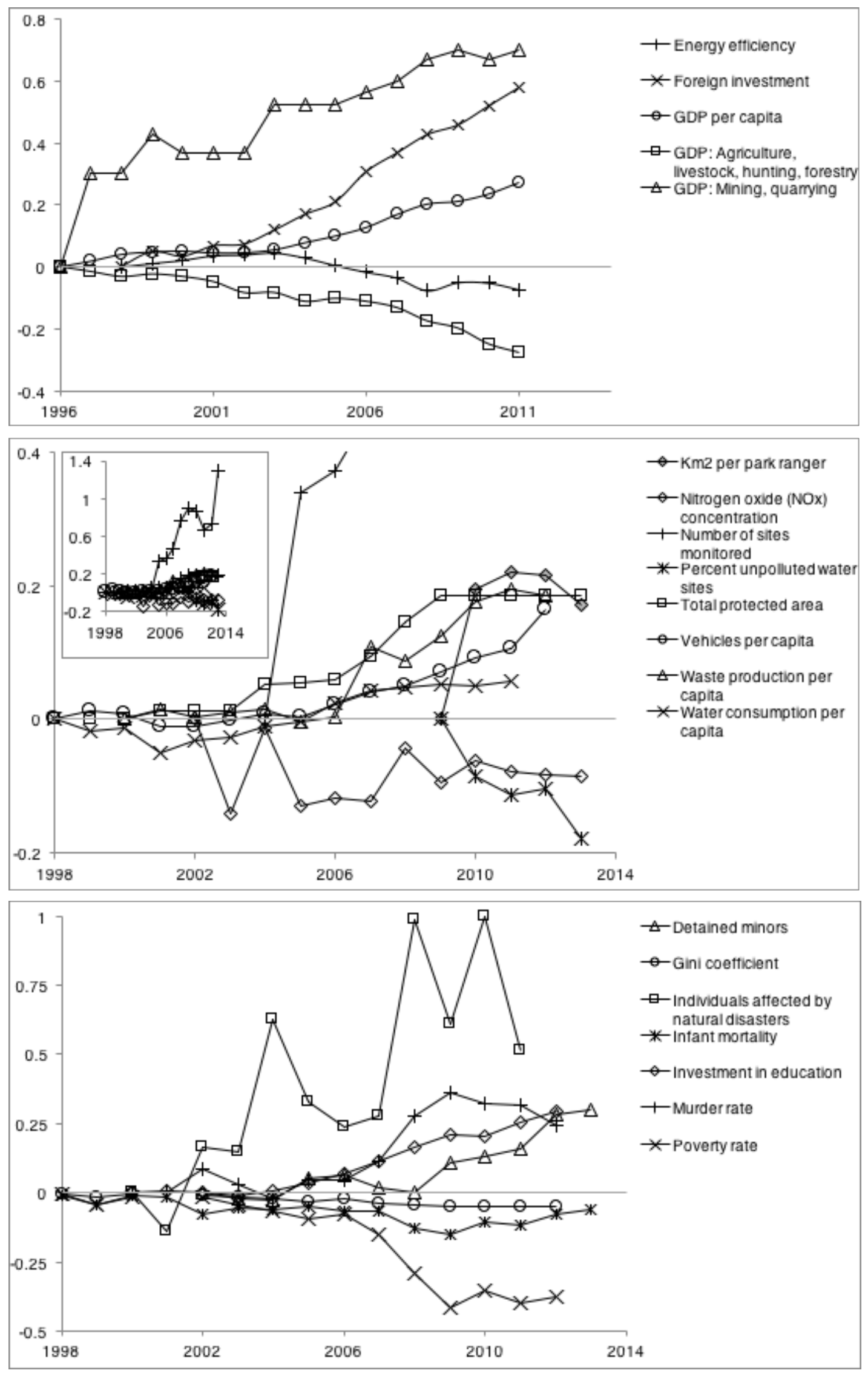


\section{Environmental}

The environmental indicators broadly address a number of themes: air quality, waste, water, protected areas, environmental monitoring effort, and transportation. Environmental indicators showed greater variation in trends than economic indicators, with most being negative from an environmental standpoint. Negative trends were most evident for waste, water, and transport. Annual waste production per capita in the Panamá and San Miguelito districts increased 53.1\% (Figure 1b) from 353.22kg in 2000 to $540.71 \mathrm{~kg}$ in 2012. Water consumption per capita decreased from $80.29 \mathrm{~m}^{3}$ in 1999 to $71.72 \mathrm{~m}^{3}$ in 2001 , before steadily climbing to $91.30 \mathrm{~m}^{3}$ in 2011 , resulting in a net increase of $13.7 \%$. Meanwhile, water quality declined nationally as the percentage of surveyed rivers categorized as unpolluted or acceptably polluted decreased from $80.38 \%$ in 2009 to $53.38 \%$ in 2013. Panama also experienced growth in the number of vehicles per capita, which rose $45.99 \%$, from 0.1035 in 1998 to 0.1511 in 2012:

The indicators also highlight some positive environmental trends in terms of monitoring effort and air quality. Improvement has been seen in the national monitoring effort for water quality: the number of sites monitored nationally increased from 84 in 2004 to 1,674 in 2013, an increase of 1892.86\%. Slight improvements in air quality are evident, with nitrogen oxides in Panama City decreasing $18.01 \%$ from $43.30 \mu \mathrm{g} / \mathrm{m}^{3}$ in 2002 to $35.5 \mu \mathrm{g} / \mathrm{m}^{3}$ in 2013 .

Indicators dealing with protected areas showed mixed trends. Amount of protected area increased $52.8 \%$ from $23,419.3 \mathrm{~km}^{2}$ in 1998 to $35,784.8 \mathrm{~km}^{2}$ in 2013 , although this number has remained unchanged since 2009. At the same time however, the number of $\mathrm{km}^{2}$ of protected area per park ranger increased $53.80 \%$ from $59.7 \mathrm{~km}^{2}$ in 2009 to $88.9 \mathrm{~km}^{2}$ in 2013 , suggesting a decrease in the quality of the protection. Of the environmental indicators, only nitrogen oxide concentration in Panama City and vehicles per capita might yield a direct causal relationship, however we found no significant relationship between these two indicators (Table 3b). Economic growth, measured by GDP, generally did not translate to improvement from an environmental standpoint (Table 3a). Increased GDP per capita was significantly correlated with an increase in environmental stressors - waste and water consumption per capita, as well as number of vehicles per capita - and had no significant correlation with nitrogen oxide levels in Panama City.

\section{Social}

Social indicators can be grouped under the following themes: income inequality, health, education, security, and natural disasters. Analysis using Pearson's correlation coefficient revealed many significant correlations within the social pillar (Table 3b). In some cases the correlation could suggest important causal relationships that could be further studied. For example the Gini coefficient, where a larger value indicates greater wealth inequality, was positively correlated with infant mortality and poverty, and was negatively correlated with investment in education. Interestingly, the Gini coefficient was also negatively correlated with the murder rate and the number of individuals detained, which were correlated with one another, and with the number of minors detained. The number of minors detained was not correlated with the number of individuals detained, however it was significantly and positively correlated with the murder rate, although less so $(\mathrm{P}<0.05)$. Additionally, we found a positive correlation between investment in education and the number of minors detained.

Because the murder rate and the number of individuals detained were correlated with one another, the latter was removed as an indicator, as it is a more indirect measure of security than the former. Although murder rate and number of minors detained are also correlated, the latter was not removed as it addresses Panama's gang problems (see Discussion). A strong and significant correlation was also found between the number of individuals and of homes affected by natural disasters; as a consequence, the latter was removed from the list of indicators. Despite the correlation between the poverty rate and the Gini coefficient, neither indicator was removed as they measure wealth differently: the former is an absolute measure, while the latter is a relative measure. Finally, despite the correlation between the Gini coefficient, the murder rate, investment in education and infant mortality, all these indicators were retained because they each measure a different facet of social wellbeing - inequality, security, education, and health.

The temporal trend in indicators revealed a mix of social progress and social problems. Improvement was seen in terms of income inequality, health, and education. Gini coefficient decreased from 58.26 in 1997 to 51.90 in 2012, a 10.92\% decrease (Figure 1c). Between 1997 and 2012, the poverty rate, measured as the percentage of the population earning less than $\$ 2$ per day (at 2005 international prices), decreased from $21.16 \%$ to $8.87 \%$. Infant mortality also decreased from 17.2 deaths per 1000 births 
in 1997 to 15.0 in 2013, a $12.8 \%$ drop; despite being an improvement since 1997, however, infant mortality reached its nadir of 12.2 in 2009 and has steadily increased since. Investment in education increased 95.85\% from 651,000 Balboas per student in 2000 to 1,275,000 in 2012.

The indicators also revealed a number of social issues of potential concern, concentrated in the areas of security and natural disasters. The number of minors detained increased from 8,805 in 2002 to 16,867 in 2012, a $91.56 \%$ increase. Similarly, the murder rate increased $75.69 \%$ from 9.79 murders per 100,000 people in 2000 to 17.20 in 2012; nonetheless, the murder rate has decreased steadily from its peak of 22.62 in 2009. Meanwhile, the number of individuals affected by natural disasters increased $225.63 \%$ from 7104 in 2000 to 23,133 in 2011; peak values were 70,510 in 2010 and 69,210 in 2008.

Comparing across pillars reveals many instances of correlation with social indicators. GDP per capita was significantly correlated with all social indicators (Table 3a). Growth in GDP translated to social improvement in some areas: GDP per capita was positively correlated with investment in education and negatively with Gini coefficient, poverty rate, and infant mortality. GDP per capita growth did not translate to improvement in all fields, however. Both the number of minors detained and the murder rate were positively correlated with GDP per capita (but see Discussion).

\subsection{Human Development Index and Ecological Footprint}

Most Latin American countries fall under the HDI threshold for "very high development", with almost all countries located in the range of 0.6 and 0.8 (Figure 2). Only Chile, Cuba, and Argentina exceed this threshold value. Similarly, almost all nations' EFs exceed the earth's estimated biocapacity, calculated at 1.78 , with most ranging from under 2 to over 5. Only four countries - Dominican Republic, Peru,

Nicaragua, and Guatemala - remain within the bounds of sustainability, however these are among the least developed according to the UNDP's HDI. With a HDI of 0.78 and an EF of 2.87, Panama positions itself at the high end the range of other countries Latin American countries for both HDI and EF. Panama, Costa Rica, and Mexico are almost identically positioned for both indices.

Fig 2. HDI and EF per capita of nations. Black denotes Panama; white represents other Latin American countries: Argentina (1), Bolivia (2), Brazil (3), Chile (4), Colombia (5), Costa Rica (6), Cuba (7), Dominican Republic (8), Ecuador (9), El Salvador (10), Guatemala (11), Honduras (12), Mexico (13), Nicaragua (14), Paraguay (15), Peru (16), Uruguay (17), Venezuela (18). Horizontal line represents Earth's biocapacity per capita. Vertical line represents UNDP threshold of "very high development". Grey box represents the "sustainability goal" of very high human development within the earth's ecological limits. 


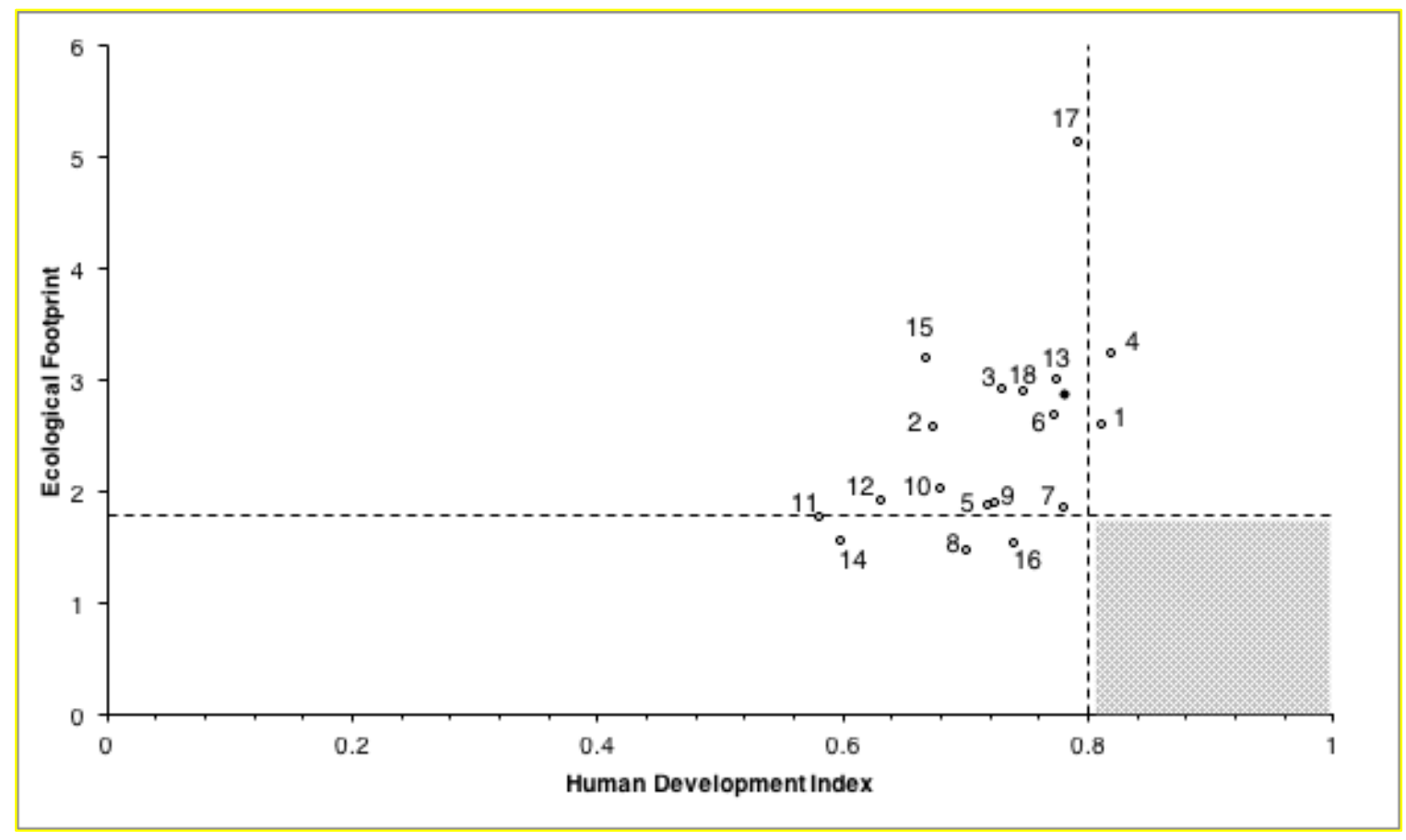

\section{Discussion}

\subsection{Participation}

Our study benefited from a relatively high net participation rate (45\%); of 94 invited persons, 42 participated in the indicator selection at some stage. Comparing participation rates with other similar initiatives is difficult because few studies explicitly report them. However, the initiative to develop ecological indicators in Ile-de-France conducted by Maxim (2012) saw 31 of 158 invited individuals participate $(20 \%)$.

Participation declined somewhat over time. In the focus group, of 22 invited individuals, 17 attended the first meeting, while only 11 attended the second. Similarly, we received only 15 responses to the web survey, despite it being circulated to 94 individuals. This decline in participation over time, dubbed "stakeholder fatigue" has been documented in other studies (Nakibinge et al., 2009; Maxim, 2012). Nonetheless, our study enjoyed consistent core participation with 8 of a possible 20 individuals participating in both focus group meetings, the workshop, and the web survey.

Our study also saw a strong governmental participation spanning multiple sectors, suggesting an encouraging willingness of the government to involve itself in sustainability initiatives. Of concern, however was a comparatively lower involvement of NGOs. The study by Maxim (2012), which experienced a similar underrepresentation of NGOs, attributes this in part to stakeholder fatigue due to "meeting overload", to which NGOs were perhaps most susceptible. A deeper analysis of the NGO sector is perhaps necessary to understand the low participation of NGOs.

\subsection{Data availability}

While compiling the preliminary list of candidate indicators, it was found that many environmental indicators advocated by focus group institutions did not have supporting data available yet. For example, looking at the final list of indicators, it is apparent that biological and ecological indicators are conspicuously lacking, despite Panama being a biodiversity hotspot, which is due to a lack of available data. Focus group and workshop participants identified change in forest cover as a desirable indicator, although this information is collected nationally with too high a periodicity for it to be informative. The launch of Global Forest Watch (http://www.globalforestwatch.org), a global online monitoring network that maps annual forest cover change, might allow the inclusion of an indicator of forest cover in the future. 
Another avenue suggested by focus group participants is to use data from the Christmas bird counts conducted by Panama's Audubon Society; indeed, bird assemblage may serve as a useful ecological indicator of habitat disturbance (Canterbury et al., 2000) for instance. This lack of available environmental data is unsurprising: as will be discussed later, such missing data has constrained the ability of certain sustainability indices, such as the Adjusted Net Savings, from properly measuring all facets of sustainability.

\subsection{The three pillars}

The participants' decision to adhere to a three-pillar structure represents a departure from recent initiatives calling for a fusion of the three pillars. "Sustainability is an essentially integrative concept", Gibson (2006) argues. Consequently, treating the economic, environmental, and social pillars separately ignores the "profound interdependence of these factors" (Gibson, 2006). Thus, numerous recent indicatordriven endeavors have sought a more unified approach.

One such attempt, broadly referred to as a "green growth" strategy, has been espoused by international organizations including the United Nations Environment Programme (UNEP), World Bank, and the Organization for Economic Co-operation and Development (OECD). According to the Green Growth Knowledge Platform (GGKP), a network of organizations that includes the OECD, World Bank, and the UNEP, green growth attempts to "fuse sustainable development's economic and environmental pillars into a single intellectual and policy planning process", where "a broader concept of 'inclusive' green growth $[\ldots]$ incorporates fully the social sustainability aspects" (GGKP, 2013).

Green Growth, as a concept, faces many complications, however. Proper fusion of economic and environmental pillars is undermined by data-limitations. Indeed the GGKP recognizes the "poor integration of economic and environmental data owing to differences in classifications and terminology, timeliness, and significant gaps in environmental-economic data" (GGKP, 2013). The lack of understanding of the relationships between pillars further hampers the ability to combine them: "further research is needed to better understand the impacts of environmental developments on economic activity, of economic activity on the environment, and of policies [...] on economic, social, and environmental outcomes" (GGKP, 2013). Taking this all into account, it is unsurprising that many Green Growth indicators proposed by the GGKP (2013) are currently unavailable.

Adjusted Net Savings (ANS) is another attempt to unite the three pillars of sustainability. Spearheaded by the World Bank, ANS seeks to incorporate economic, environmental, and human capital into a national accounting framework. This is broadly accomplished by adjusting a country's net national savings to account for expenditures on education (normally treated as a consumption; in ANS this is considered an investment in human capital), natural resource depletion, and estimated economic damage associated with carbon dioxide and particulate pollution (World Bank, 2010). A negative ANS would indicate that a country is eating away at its savings and therefore progressing unsustainably.

Although the ANS incorporates aspects of social and environmental sustainability, representation of these pillars in the ANS's current formulation (World Bank, 2010) is greatly reduced. Focusing exclusively on human capital, and more specifically education, ANS ignores many other important aspects of social sustainability such as health or equity. ANS also takes no account of other markers of environmental degradation such as biodiversity loss, water resource depletion and quality decline, or soil degradation omissions explained by a lack of comparable data (Stiglitz et al., 2010). However, even for those assets measured, valuation is skewed; as Stiglitz et al. (2010) note: "As sustainability always involves a view of the future, pricing $\mathrm{CO} 2$ emissions is only partially a problem of what $\mathrm{CO} 2$ emissions costs now, but rather how much those should be priced tomorrow."

These two examples illustrate a common barrier to accurate and representative integration of the three pillars: information deficit. An insufficient understanding about the interaction between pillars and a lack of environmental data mean that any attempt to present an integrated picture of sustainability risks being inaccurate and undervaluing social and, especially, environmental aspects. This is potentially dangerous, particularly if the new framework is presented under the guise of being truly integrative.

It should be noted that the focus group's decision to supplement the dashboard of indicators with the HDI and EF demonstrates a holistic, integrative view of sustainability on the part of the participants. The juxtaposition of the two indices presents the economic, environmental, and social spheres as interlinked. As shall be discussed later, this measure of sustainability is insufficient. Yet, given the shortage of environmental data and of knowledge about inter-pillar links, the juxtaposed HDI and EF may be one of the 
best available options that integrates the three pillars and does not rely on unavailable information. However, the juxtaposed HDI and EF retain all the shortcomings inherent to composite indices and are clearly insufficient as a measure of sustainability; instead they remain an addendum that serves only to supplement the dashboard of sustainability indicators, which firmly stands on three distinct pillars.

Indeed, given the present state of knowledge, then, the three-pillar system, adopted by Panama in this study, may present the best available recourse. The three-pillar approach risks misrepresenting sustainability as a disjointed concept, potentially leading decision-makers to overlook important links between pillars. However, to wait on the collection of future data and the creation of future indicators could have more severe implications. Given the pressing nature of deteriorating global environmental conditions, countries must make use of what is available until new methods of measuring sustainability emerge.

\subsection{Panama}

The dashboard of sustainability indicators points to a number of important issues in Panama. Here we focus on three in particular: security, vehicles and vehicle emissions, and natural disasters.

\subsubsection{Security}

Security is a cause for national concern in Panama. Indeed, during the workshops, security was among the most cited themes to be addressed by the dashboard of indicators. Latin America suffers from a disproportionately high crime rate: 41 of the world's 50 "most violent" cities are located in the region (Ortega, 2014). Panama has a relatively low crime rate compared with other Central American countries (OSAC, 2013). However, Panama's geographic position makes it a strategic point for organized crime operations, serving as a distribution hub for the drugs and arms trades (Ministerio de Seguridad Pública, 2010). The Revolutionary Armed Forces of Colombia (FARC), for instance, has been known to transit through Panama's Darién region, a densely forested area bordering Colombia (Watts \& Ruff, 2012). Panama is also experiencing a growth in the number of pandillas or gangs at a rate of $10 \%$ annually (Ministerio de Seguridad Pública, 2010). Almost inexistent prior to the 2000s, gangs in Panama have surged in numbers due to the country's relatively young population and inadequate education and afterschool programs (Watts and Ruff, 2012).

Our results indicate that the number of minors detained have increased consistently from 1998 to 2010, and has been in slow decline since. This statistic may indicate a decline in crime in recent years, however it could also indicate a decreased national effort to curtail crime. A decreased police presence, for instance, would decrease the likelihood of crimes going unpunished and thus the number of arrests.

However, the dashboard's murder rate indicator shows a similar trajectory: murder rates increased steadily from 2004, with pronounced increases in 2008 and 2009, and decreased thereafter. These results possibly suggest that the recent decrease in minors detained is indicative of an improving security situation rather than a worsening one.

This recent improvement follows efforts by the country's previous government, Cambio Democratico, to reduce crime though more stringent law enforcement. Cambio Democratico, led by Ricardo Martinelli, has accused previous governments of "having a friendly deal with drug traffickers and guerrillas that has ended under [Martinelli's] government" (Borkan, 2010). Indeed, it was revealed that Panama's former presidents Mireya Moscoso and Martín Torrijos had allegedly formed "non-aggression pacts" with the FARC (Alsema, 2010). The Martinelli government's intensified efforts to curtail crime have yielded some positive results: for instance, under Martinelli, Panama intercepted almost twice as many drugs as the previous government in the same amount of time. This increase has been lauded as an indication of increased policing effort, rather than of an increase in drug-related activity (Rodríguez, 2014).

However, despite improvement in recent years, security remains a problem in Panama. The murder rate in 2012, the most recent year for which data is available, was still more than 50\% higher than it was for any year between 2000 and 2006. Some forms of crime, such as rape and theft, actually increased between 2009 and 2012; others, such as burglary, have remained unchanged (OSAC, 2013).

Nonetheless, these concerted efforts to tackle drug- and gang-related criminal activity demonstrate a willingness of the government to address these important social issues. With social inequality, poverty, and education believed to be at the root of some of Panama's crime problems (Watts and Ruff, 2012), we may expect further security improvements as the country continues to improve in these areas, as our results show. 


\subsubsection{Vehicles}

The increase in the number of vehicles per capita in Panama is at once economically promising and of environmental concern. Like in many countries (Dargay et al., 2007), economic growth in Panama has allowed individuals to enjoy a higher purchasing power, such that more individuals can afford personal vehicles. This conclusion is consistent with the correlation between GDP per capita and vehicles per capita that we observed.

However, a larger number of vehicles per capita simultaneously represents a significant health concern and an increased environmental stressor. Particulate matter and $\mathrm{NO}_{2}$ released in vehicle emissions negatively impact respiratory and cardiovascular systems, with increased exposure resulting in greater health risks (WHO, 2003). In addition, vehicle emissions are a significant source of greenhouse gases such as $\mathrm{CO}_{2}, \mathrm{CH}_{4}$, and $\mathrm{N}_{2} \mathrm{O}$, which contribute to global climate change (Kirtman et al., 2013).

Despite the number of vehicles per capita increasing, air quality in Panama City appears to have slightly improved, with recorded nitrogen oxide levels in the city decreasing since 2002. Such a result is surprising as nitrogen oxide is a strong indicator of vehicle emissions (WHO, 2003), and should then increase with the number of vehicles per capita.

The fact that the two indicators are measured at different spatial scales does not account for this surprising result. Indeed, if vehicles per capita increased primarily outside of Panama City, we might expect the observed stasis of nitrogen oxide levels in the capital despite a national increase in vehicles per capita. However, the province of Panamá, of which 50\% of the population resides in Panama City (Contraloría, 2010b), has seen the number of vehicles rise from 239,111 in 2002 (Contraloría, 2002) to 458,391 in 2013 (Contraloría, 2013a), a 91.7\% increase. This percentage increase is amongst the highest in the country. The province with the most number of vehicles after Panamá province is Chiriquí, which increased from 32,473 in 2004 to 51,576 in 2011 - a marginal increase by comparison.

Nor is it likely that the stabilization of nitrogen oxide levels in Panama City is due to improved environmental standards for vehicles. Panama recently passed legislation limiting sulfur content of gasoline and diesel to 500 parts per million (ppm) (Secretaría Nacional de Energía, 2014). These regulations, which reduce emissions of sulfur oxides but not of nitrogen oxides, are relatively strict compared to some Latin American countries (UNEP, 2015), but far less so than those in place in the United States (EPA, 2000) and Europe (EU, 2003). And unlike the United States (EPA, 2006) and Europe (EU, 2007), Panama has yet to implement vehicle emission standards that would limit emissions of nitrogen oxide, particulate matter, and other pollutants (Secretaría Nacional de Energía, 2014).

Instead, the observed result may be caused by other unrelated factors. Following the opening of two new highway corridors in 1997, the amount of particulate matter in Panama City decreased by approximately $25 \%$ and remained relatively stable at these lower values (Asociación Panameña de Ejecutivos de Empresa, 2013). Whether a similar explanation applies for nitrogen oxides is unclear, however it suggests that urban pollution is the product of multiple factors. This outcome is encouraging, as it suggests that many actions can be taken to mitigate the effects of the increased number of vehicles in Panama.

Despite the encouraging trend of nitrogen oxide concentrations in Panama City, nitrogen oxide levels remain very close to the limit set by the World Health Organization of $40 \mu \mathrm{g} / \mathrm{m} 3$ (WHO, 2003). Indeed, recorded maximal values have exceeded $50 \mu \mathrm{g} / \mathrm{m} 3$ for three of the five most recent years for which data is available (Contraloría, 2013b). Meanwhile, the station at San Miguelito, the neighboring district to Panama City, has experienced unwavering mean annual nitrogen oxide values around $50 \mu \mathrm{g} / \mathrm{m} 3$ since 2002 (Contraloría, 2006; 2010a).

\subsubsection{Natural disasters}

Panama has experienced a notable increase in the number of individuals affected by natural disasters annually over time. Natural disasters are difficult to avoid and to predict. However, with their frequency and intensity expected to increase under global climate change (IPCC, 2014; Kirtman et al., 2013; GFDRR, 2014), countries must ensure they are adequately prepared to effectively confront and respond to them; such proactive measures would help minimize human and economic loss in future disaster events.

Improved disaster management is of utmost importance for Panama, especially: the Global Facility for Disaster Reduction and Recovery (GFDRR) ranks Panama as the $14^{\text {th }}$ country in the world most exposed to 
multiple hazards (GFDRR, 2014). Indeed, Panama is prone to extreme weather: in 2008 and 2010, the country experienced severe floods nationwide at the hands of "la Purísima", a name given to tropical storms often occuring around the date of the religious holiday of the same name ("Al menos siete muertos $y$ más de 30.000 damnificados dejan lluvias en Panamá", 2008; "La Purísima causó 500 deslizamientos de tierra", 2011). However, Panama also often experiences landslides, earthquakes, tsunamis, wildfires, and windstorms (Global Facility for Disaster Reduction and Recovery, 2014).

According to a UN enquiry, part of Panama's vulnerability to natural disasters is due to the country's current management: enforcement of land use regulations is inefficient, compliance with building codes is uncertain, and urban and industrial expansion are largely unplanned (GFDRR, 2012).

Encouragingly, however, the government of Panama has recently begun to change its natural disaster strategy. Previously focusing on emergency preparedness, the government has started to implement proactive measures that seek to reduce risk. In 2005, it created the National Civil Protection System, in charge of coordinating disaster risk management (GFDRR, 2009). Since 2010, the country has also sought to introduce disaster risk reduction strategies to the government's various sector institutions. The Ministry of Finance for instance has included a component of the Panamanian Savings Fund devoted to disaster risk protection. The Ministry of Land Use Planning (MIVIOT), meanwhile, has begun to integrate disaster risk criteria in the design of land use plans (GFDRR, 2012).

\subsection{HDI and Ecological Footprint}

Pairing of the HDI with the EF is a useful complement to Panama's dashboard of indicators because i) they allow for comparison with other countries and ii) together, these indices touch upon the three pillars of sustainability.

The HDI was first proposed in the UNDP's first Human Development Report in 1990. Positing that the enlargement of choice is the true goal of human development, the report argued that three fundamental choices must first be made accessible: "to lead a long and healthy life, to acquire knowledge and to have access to resources needed for a decent standard of living" (UNDP, 1990, p. 10). These three points formed the basis for the creation of the HDI, which is calculated by aggregating the values of four indicators: life expectancy at birth, mean years of schooling for adults aged 25 years and expected years of schooling for children of school entering age, and gross national income at purchasing power parity (Malik, 2014). This formulation allows for a more comprehensive indication of development by incorporating both economic and social measures of progress. Thus the HDI addresses key aspects of two of the three pillars of sustainability.

The HDI is not a true index of sustainability, however, as it does not indicate whether a given level of development is tenable over the long term. Thus, although the HDI touches upon the economic and social pillars of sustainability, it is not a true representation of either; instead, it is a measure of economic and social wellbeing at the present moment. However, the HDI can be matched against a nation's environmental impact to capture an indication of sustainability of a given level of human development, although this approach ignores both economic and social sustainability. However, given that both economy and society are constrained by the ultimate biophysical limits of the Earth and that these limits are already being challenged by current modes of development (Maréchal, 2000), such an approach may be permissible. And surely, most efforts to supplement the HDI with a measure of sustainability have focused on including environmental and resource-consumption dimensions (Pineda, 2012).

Most popular among these efforts has been the juxtaposition of the HDI with the EF (eg. Moran et al., 2008; Neumayer, 2012), an index of environmental sustainability. The EF is a measure of the demand of human activity on the biosphere's resources and services. This demand is measured as the amount of biologically productive land and water area required to sustain the given population and its consumption patterns, for example by producing food or assimilating waste. The EF allows for comparison by standardizing all of the earth's biologically productive area to a common area unit, the global hectare. A country's ecological demand of global hectares per capita - its "footprint" - is then typically compared to the earth's biocapacity, the total global hectares divided by the total human population (Ewing et al., 2010). A footprint that exceeds the global biocapacity indicates that a nation is proceeding unsustainably.

The EF has, however, been criticized for its method of aggregating and normalizing land area under the global hectare (Stiglitz et al., 2010). To calculate national footprints, the EF weights land areas according to their agricultural productivity. Under this framework, the productivity of one hectare of forest is half that of cropland and is consequently weighted less heavily when converting these areas to global 
hectares. A country may then increase its biocapacity, reducing its ecological deficit, by converting forested lands to croplands (Stiglitz et al., 2010).

The sustainability goal is for countries to achieve very high development as defined by the UNDP (HDI $\geq 0.8$ ) and an EF within the limits of the earth's biocapacity (1.78) (Moran et al., 2008; Neumayer, 2012). Panama, with an HDI of 0.78, is close to achieving this development goal. However, its EF of 2.87 places it well beyond the earth's biocapacity. With respect to other Latin American countries, Panama is among the more developed nations but also those with the highest footprints. This picture of Panama as an economically and socially strong but environmentally weak nation is consistent with the one derived from the dashboard of indicators, which showed economic and social improvement over the past decade but environmental stagnation and deterioration.

\section{Conclusion}

This study combines a top-down and bottom-up participatory approach to selecting national-scale, sustainability indicators. Adhering to a three-pillar structure, the resulting dashboard of indicators is a useful tool for understanding past trends, present issues, and future trajectories within Panama's economic, environmental, and social spheres. Information provided by the dashboard can be dissected and extrapolated further, as we have done for three example issues - security, vehicles and vehicle emissions, and natural disasters.

The designation of national sustainability indicators is a key step for countries hoping to follow a sustainability agenda. A report by the Finnish Ministry of the Environment credited Finland's use of indicators as "a core element of the strategy work related to sustainable development", and a means through which "the strategy for sustainable development has been enhanced and the contents of the target areas [...] become more concrete" (Ministry of the Environment, 2009). Similarly, Rinne et al. (2013) demonstrated the application of indicators to be highly influential in the monitoring, evaluation, and revision of sustainable development strategies in the European Union. Thus by developing and implementing its own dashboard of sustainability indicators, Panama takes important strides toward advancing its own sustainability goal.

\section{Acknowledgements}

Research reported in this publication was supported by the Natural Sciences and Engineering Research Council of Canada to C.P. We would like to thank all the individuals and organizations that participated in either the focus groups or workshops. In particular, we are indebted to Dr. Emilio Messina, Mrs. Elia Guerra, Dr. Ana Spalding, Mr. Rodrigo Guardia, Mrs. Yanet Sierra, and Mrs. Marta Domingo for their insight and cooperation in the indicator compilation process. Additional thanks extended to the Smithsonian Tropical Research Institute for use of their facilities, to Mrs. Lady Mancilla for coordinating and organizing the meetings, and to Dr. Andy Gonzalez for his comments on an earlier version of the manuscript.

\section{References}

Al menos siete muertos y más de 30.000 damnificados dejan lluvias en Panamá. 2008, 25 November. La Tercera. http://www.latercera.com/contenido/678_77776_9.shtml (accessed 30.07.15).

Alsema, A. 2010, June 27. Panama had non-aggression pact with FARC. Colombia reports. http://colombiareports.com/panama-had-non-aggression-pact-with-farc/ (accessed 30.07.15).

Asociación Panameña de Ejecutivos de Empresa. 2013. Causas y consecuencias de la contaminación del aire sobre la salud en Panamáhttp://www.apede.org/descargas/carta-ambiental/11-carta-ambientalmarzo-2013/file.html (accessed 30.07.15).

Bell, S., Morse, S., 2003. Measuring Sustainability - Learning From Doing. Earthscan, London, UK.

Bossel, H., 1999. Indicators for Sustainable Development: Theory, Method, Applications. A Report to the Balaton Group, IISD, Canada.

Borkan, B. 2010, June 28. Panama confirms FARC presence within borders. Colombia reports. http://colombiareports.co/panama-minister-confirms-farc-presence-within-borders/ (accessed 30.07.15). 
Bradley Guy, G., Kibert, C. J., 1998. Developing indicators of sustainability: US experience. Building Research \& Information, 26(1), 39-45.

Canterbury, G. E., Martin, T. E., Petit, D. R., Petit, L. J., Bradford, D. F., 2000. Bird communities and habitat as ecological indicators of forest condition in regional monitoring. Conservation Biology, 14(2), 544-558.

Chamaret, A., O’Connor, M., Récoché, G., 2007. Top-down/bottom-up approach for developing sustainable development indicators for mining: application to the Arlit uranium mines (Niger). International Journal Sustainable Development 10 (1/2), 161-174.

Contraloría. 2002. Automóviles en circulación en la República, por provincia, según tipo: Año 2002. http://www.contraloria.gob.pa/inec/archivos/P2041CUADRO02.pdf (accessed 30.07.15).

Contraloría. 2006. Concentraciones promedio de óxidos de nitrogeno registradas en la ciudad de Panamá, por estación: Años 2002-2006. http://www.contraloria.gob.pa/inec/Archivos/P290119.pdf (accessed 30.07.15).

Contraloría. 2010a. Concentraciones promedio de óxidos de nitrogeno registradas en la ciudad de Panamá, por estación: Años 2006-2010. http://www.contraloria.gob.pa/inec/archivos/P516119.pdf (accessed 30.07.15).

Contraloría. 2010b. Superficie, población y densidad de población en la Republica según provincia, comarca indigena, distrito y corregimiento: censos de 1990 a 2010. https://www.contraloria.gob.pa/inec/archivos/P3561Cuadro4.xls (accessed 30.07.15).

Contraloría. 2013a. Automóviles en circulación en la República, por provincia, según tipo: Año 2013. http://www.contraloria.gob.pa/inec/archivos/P6651333-02.pdf (accessed 30.07.15).

Contraloría. 2013b. Concentraciones promedio de óxidos de nitrogeno registradas en la ciudad de Panamá, por estación: Años 2008-2013. http://www.contraloria.gob.pa/INEC/archivos/P641112.pdf (accessed 30.07.15).

Côté, A., McCollough, D., 2007. Comparative analysis of indicator systems for sustainable development. Quebec: Developpement durable, Environnement et Parcs.

Crabtree, B., Bayfield, N., 1998. Developing sustainability indicators for mountain ecosystems: a study of the Cairngorms, Scotland. Journal of Environmental Management, 52(1), 1-14.

Dargay, J., Gately, D., Sommer, M., 2007. Vehicle ownership and income growth, worldwide: 19602030. The Energy Journal, 28(4), 143-170.

Duinker, P.N., 2001. Criteria and indicators of sustainable forest management in Canada: progress and problems in integrating science and politics at the locallevel. In: Franc, A., Laroussinie, O., Karjalainen, T. (Eds.), Criteria and Indicators for Sustainable Forest Management at the Forest Management Unit Level. EFI Proceedings No. 38., pp. 7-29.

Ekins, P., Simon, S., Deutsch, L., Folke, C., De Groot, R. 2003. A framework for the practical application of the concepts of critical natural capital and strong sustainability. Ecological economics, 44(2), $165-185$.

EPA. 2000. Control of Air Pollution from New Motor Vehicles: Tier 2 Motor Vehicle Emissions Standards and Gasoline Sulfur Control Requirements; Final Rule. Fed Reg., 65:6698-6870.

EPA. 2006. Program update: Introduction of cleaner-burning diesel fuel enables advances pollution control for cars, trucks and buses. Office of Transportation and Air Quality, EPA420-F-06-064.

EU. 2003. Directive 2003/87/EC of the European Parliament and of the Council of 13 October 2003 establishing a scheme for greenhouse gas emission allowance trading within the Community and amending Council Directive 96/61/EC. OJ L 275, 25.10.2003, 32-46.

EU. 2007. Euro 5 and Euro 6 standards: Reduction of pollutant emissions from light vehicles. OJ L 171, 29.6.2007, 1-16.

Ewing, B., Moore, D., Goldfinger, S., Oursler, A., Reed, A., Wackernagel, M., 2010. The Ecological Footprint Atlas 2010. Global Footprint Network, Oakland.

Foro y Observatorio de Sostenibilidad. 2012. Resumen y análisis. Retrieved from: http://www.cich.org/publicaciones/STRI-INDICASAT-2012-Foro-de-Sostenibilidad.pdf

Gibson, R. B., 2006. Beyond the pillars: sustainability assessment as a framework for effective integration of social, economic and ecological considerations in significant decision-making. Journal of Environmental Assessment Policy and Management, 8(03), 259-280.

GFDRR. Disaster risk management in Central America: GFDRR country notes: Panama. http://www.gfdrr.org/sites/gfdrr.org/files/Panama_DRM.pdf (accessed 30.07.15). 
GFDRR. 2009. Disaster risk management programs for priority countries: Summary 2009. http://www.unisdr.org/files/14757_6thCGCountryProgramSummaries1.pdf (accessed 30.07.15).

GFDRR. 2012. Panama country update. http://www.gfdrr.org/sites/gfdrr.org/files/PANAMA.pdf (accessed 30.07.15).

GGKP. 2013. Moving towards a Common Approach on Green Growth Indicators: A Green Growth Knowledge Platform Scoping Paper.

Hall, J. P. 2001. Criteria and indicators of sustainable forest management. Environmental Monitoring and Assessment, 67(1-2), 109-119.

Heal, G. 2012. Reflections - defining and measuring sustainability. Review of Environmental Economics and Policy, 6(1), 147-163.

Kirtman, B., et al., 2013. Near-term Climate Change: Projections and Predictability. In: Climate Change 2013: The Physical Science Basis. Contribution of Working Group I to the Fifth Assessment Report of the IPCC. Cambridge University Press, Cambridge, United Kingdom and New York, NY, USA.

La Purísima causó 500 deslizamientos de tierra. 2011, December 9. La Prensa. http://impresa.prensa.com/panorama/Purisima-causo-deslizamientos-tierra_0_3269673196.html (accessed 30.07.15).

Liverman, D. M., Hanson, M. E., Brown, B. J., Merideth Jr, R. W., 1988. Global sustainability: toward measurement. Environmental management, 12(2), 133-143.

Malik, K., 2014. Human Development Report 2014 - Sustaining Human Progress: Reducing Vulnerabilities and Building Resilience. New York, NY: UNDP.

Maréchal, J.-P., 2000. Humaniser l'économie. Desclée de Brouwer, Paris.

Maxim, L., 2012. Building shared socio-economic indicators for biodiversity. A case study in the Ile-deFrance region (France). Ecological Indicators, 13(1), 347-357.

Messina, E., 2012. Dialogo pedagógico con la naturaleza: la educación que salvara el planeta. UDELAS, Panama.

Ministerio de Seguridad Publica. 2010. Informe de criminalidad, año 2010. http://www.siec.gob.pa/Content/Files/INFORME\%20DE\%20CRIMINALIDAD\%20DEL\%202010. pdf (accessed 30.07.15).

Ministry of the Environment. 2009. National Assessment of Sustainable Development 2009. Ministry of the Environment, Helsinki. www.ymparisto.fi/download.asp?contentid=119228\&lan=fi (accessed 30.07.15).

Moran, D. D., Wackernagel, M., Kitzes, J. A., Goldfinger, S. H., Boutaud, A., 2008. Measuring sustainable development-Nation by nation. Ecological economics, 64(3), 470-474.

Nakibinge, S., Maher, D., Katende, J., Kamali, A., Grosskurth, H., Seeley, J., 2009. Community engagement in health research: two decades of experience from a research project on HIV in rural Uganda. Tropical Medicine \& International Health, 14(2), 190-195.

Nardo, M., Saisana, M., Saltelli, A., Tarantola, S., Hoffman, A., Giovannini, E., 2005. Handbook on constructing composite indicators: methodology and user guide (No. 2005/3). OECD publishing.

Neumayer, E., 2012. Human development and sustainability. Journal of Human Development and Capabilities, 13(4), 561-579.

Niemeijer, D., de Groot, R. S., 2008. A conceptual framework for selecting environmental indicator sets. Ecological indicators, 8(1), 14-25.

Ortega, J. 2014, January 15. Por tercer año consecutivo, San Pedro Sula es la ciudad más violenta del mundo. Seguridad, Justicia y Paz. http://www.seguridadjusticiaypaz.org.mx/sala-de-prensa/941-portercer-ano-consecutivo-san-pedro-sula-es-la-ciudad-mas-violenta-del-mundo (accessed 30.07.15).

OSAC. 2013. Panama 2013 crime and safety report. https://www.osac.gov/pages/ContentReportDetails.aspx?cid=14201 (accessed 30.07.15).

Reed, M. S., Fraser, E. D., Dougill, A. J., 2006. An adaptive learning process for developing and applying sustainability indicators with local communities. Ecological Economics, 59(4), 406-418.

Rinne, J., Lyytimäki, J., Kautto, P., 2013. From sustainability to well-being: Lessons learned from the use of sustainable development indicators at national and EU level. Ecological indicators, 35, 35-42.

Rodríguez, R. 2014, April 3. Ministro Mulino presentó informe sobre la situación actual de la criminalidad en Panamá [Press release].

http://www.minseg.gob.pa/index.php?option=com_k2\&view=item\&id=398:2014-04-03-20-1027\&Itemid=344 (accessed 30.07.15). 
Secretaría Nacional de Energía. 2014. Combustibles Limpios y Vehículos Más Eficientes: Reduciendo Emisiones en América Central. Retrieved from: http://www.unep.org/Transport/new/PCFV/pdf/CostaRica2014_DavidMu.pdf

Spangenberg, J. H., Pfahl, S., Deller, K., 2002. Towards indicators for institutional sustainability: lessons from an analysis of Agenda 21. Ecological indicators, 2(1), 61-77.

Stiglitz, J.E., Sen, A., Fitoussi, J.P., 2009. Report by the Commission on the Measurement of Economic Performance and Social Progress.

UN. 1992. Results of the World Conference on Environment and Development: Agenda 21. UNCED United Nations Conference on Environment and Development, Rio de Janeiro, United Nations, New York.

UNDP. 1990. Human development report 1990. Oxford University Press, New York.

UNEP. 2015. Status of Quality and Vehicle Emission Standards: Latin America and the Caribbean. http://www.unep.org/transport/pcfv/PDF/Maps_Matrices/LAC/matrix/LAC_sulphurmatrix_august2 011.pdf (accessed 30.07.15).

UN General Assembly. 2015. Transforming Our World: The 2030 Agenda for Sustainable Development A/RES/70/1.

Verbruggen, H., Kuik, O., 1991. Indicators of sustainable development: an overview. In: In Search of Indicators of Sustainable Development [Kuik, O. and Verbruggen, H. (eds.)]. Kluwer, Dordrecht, pp. 1-6.

Watts, M., Dannels Ruff, K., 2012. Drugs, Thugs, and the Diablos Rojos: Perils and Progress in Panama. Latin American Policy, 3(2), 208-234.

World Bank. 2010. Calculating Adjusting Net Saving. http://siteresources.worldbank.org/ENVIRONMENT/Resources/Calculating_Adjusted_Net_Saving. pdf (accessed 30.07.15).

World Commission on Environment and Development. 1987. Our common future. Oxford University Press, Oxford.

WHO. 2003. Health aspects of air pollution with particulate matter, ozone and nitrogen dioxide - Report on a WHO working group. Bonn, Germany, EUR/03/5042688. 


\begin{tabular}{lccc} 
& Focus group & Workshop & Tota \\
\hline NGO & 5 & 5 & 8 \\
Governmental & 14 & 14 & 23 \\
Academic & 0 & 9 & 9 \\
Private & 1 & 2 & 2
\end{tabular}


ECONOMIC

Energy efficiency: Measured as total energy production in kilowatt-hours in the Republic of Panama divided by GDP per capita at purchaser's prices in Balboas at 1996 prices.

Foreign investment: Total value of holdings in the Republic of Panama by foreign investors in millions of Balboas.

GDP per capita: GDP per capita at purchaser's prices in Balboas at 1996 prices in the Republic of Panama.

GDP \% - Agriculture, livestock, hunting, forestry: Percent of GDP accounted for by agriculture, livestock, hunting and forestry sector.

GDP \%-Mining and quarrying: Percent of GDP accounted for by mining and quarrying sector.

\section{ENVIRONMENTAL}

$\mathrm{Km}^{2}$ of protected area per park ranger: Total area of designated protected areas per park ranger in the Republic of Panama.

Nitrogen oxide in Panama City: Mean atmospheric concentration of nitrogen oxides in Panama City. Data obtained from Instituto Especializado de Análisis at Universidad de Panamá and from Contraloría.

Number of sites monitored for water quality: Number of river sites monitored for water quality by ANAM (now MiAmbiente) in the Republic of Panama. Data obtained from ANAM.

Percent of rivers unpolluted: Percent of rivers monitored during dry season by ANAM (now MiAmbiente) in the Republic of Panama classified as "unpolluted" or "acceptably polluted" by ANAM. Data obtained from ANAM.

Total designated protected area: Total area of designated protected areas in the Republic of Panama. Vehicles per capita: Total number vehicles per capita in the Republic of Panama. Population data obtained from World Bank.

Waste production per capita: Annual disposal of solid waste in Cerro Patacón landfill, Panama City. Population was determined for districts of Panamá and San Miguelito, the two districts whose waste goes to Cerro Patacón. Population values for each district were obtained from Contraloría census data for 2000 and 2010, with intermediate and post-2010 values calculated using relative (exponential) growth rate based on the two census values.

Water consumption per capita: Total annual consumption of potable water per capita in thousands of gallons. Population data obtained from World Bank.

\section{SOCIAL}

Gini coefficient: Gini coefficient for the Republic of Panama. The GINI index measures equality of income distribution in a country, with 0 representing perfect equality and 100 representing perfect inequality. Data obtained from World Bank.

Infant mortality: Infant mortality within the first year. Calculated as number of deaths within the first year of life for every 1000 live births.

Investment in education: Public sector budget allocated to education per student in the Republic of Panama in thousands of Balboas.

Murder rate: Number of intentional homicides per 100,000 individuals. Data on number of homicides obtained from United Nations Office on Drugs and Crime. Data on population obtained from World Bank.

Number of dwellings affected per year by natural disasters: Total number of individuals affected by natural disasters in the Republic of Panama.

Number of individuals affected per year by natural disasters: Total number of individuals affected by natural disasters in the Republic of Panama. Includes persons affected, wounded and killed by a natural disaster, annually.

Number of individuals detained: Total number of individuals detained annually in the Republic of Panama. 
Number of minors detained: Total number of minors detained annually in the Republic of Panama.

Poverty rate: Percent of population in the Republic of Panama living on less than $\$ 2$ a day at 2005 international prices, annually. Data obtained from World Bank. 


\begin{tabular}{ll} 
& GDP per capita \\
\hline Foreign investment & $0.9966451^{\star \star}$ \\
GDP \% Agriculture & $-0.9566395^{\star \star}$ \\
GDP \% Mining, quarrying & $0.9297718^{\star *}$ \\
GDP \% Hotels, restaurants & $0.9796403^{\star *}$ \\
\hline Detained individuals & $0.8116104^{\star *}$ \\
Detained minors & $0.8239252^{\star *}$ \\
Gini coefficient & $-0.9371959^{\star *}$ \\
Infant mortality & $-0.8464165^{\star *}$ \\
Investment in education per student & $0.9882352^{\star *}$ \\
Murder rate & $0.9030285^{\star *}$ \\
Poverty rate & $-0.9701729^{\star *}$ \\
\hline Nitrogen oxide concentration & -0.0744457 \\
Vehicles per capita & $0.9698694^{\star *}$ \\
Waste production per capita & $0.9418324^{\star *}$ \\
Water consumption & $0.9268205^{\star *}$
\end{tabular}

\begin{tabular}{|c|c|c|c|c|c|c|}
\hline & $\begin{array}{l}\text { Nitrogen oxide } \\
\text { concentration }\end{array}$ & $\begin{array}{l}\text { Detained } \\
\text { individuals }\end{array}$ & $\begin{array}{l}\text { Detained } \\
\text { minors }\end{array}$ & Gini coefficient & $\begin{array}{l}\text { Individuals } \\
\text { affected by } \\
\text { natural disasters }\end{array}$ & Poverty rate \\
\hline Vehicles per capita & -0.0496258 & -- & -- & -- & -- & -- \\
\hline Detained individuals & -- & 1 & 0.2640930 & $-0.8533316^{\star *}$ & -- & $-0.8442487^{\star *}$ \\
\hline Detained minors & -- & 0.2640930 & 1 & $-0.6579026^{*}$ & -- & $-0.6964985^{\star *}$ \\
\hline Gini coefficient & -- & $-0.8533316^{* *}$ & $-0.6579026^{*}$ & 1 & -- & $0.9521702^{\star *}$ \\
\hline Homes affected by natural disasters & -- & -- & -- & -- & $0.9268681^{* *}$ & -- \\
\hline Infant mortality & -- & -- & -- & $0.8625265^{\star *}$ & -- & $0.8587139^{* *}$ \\
\hline Investment in education per student & -- & $0.7485274^{\star \star}$ & $0.8645779^{* *}$ & $-0.8822913^{\star *}$ & -- & $-0.9499368^{\star *}$ \\
\hline Murder rate & -- & $0.8194508^{* *}$ & $0.5468383^{*}$ & $-0.8306753^{\star *}$ & -- & $-0.9416898^{\star *}$ \\
\hline
\end{tabular}



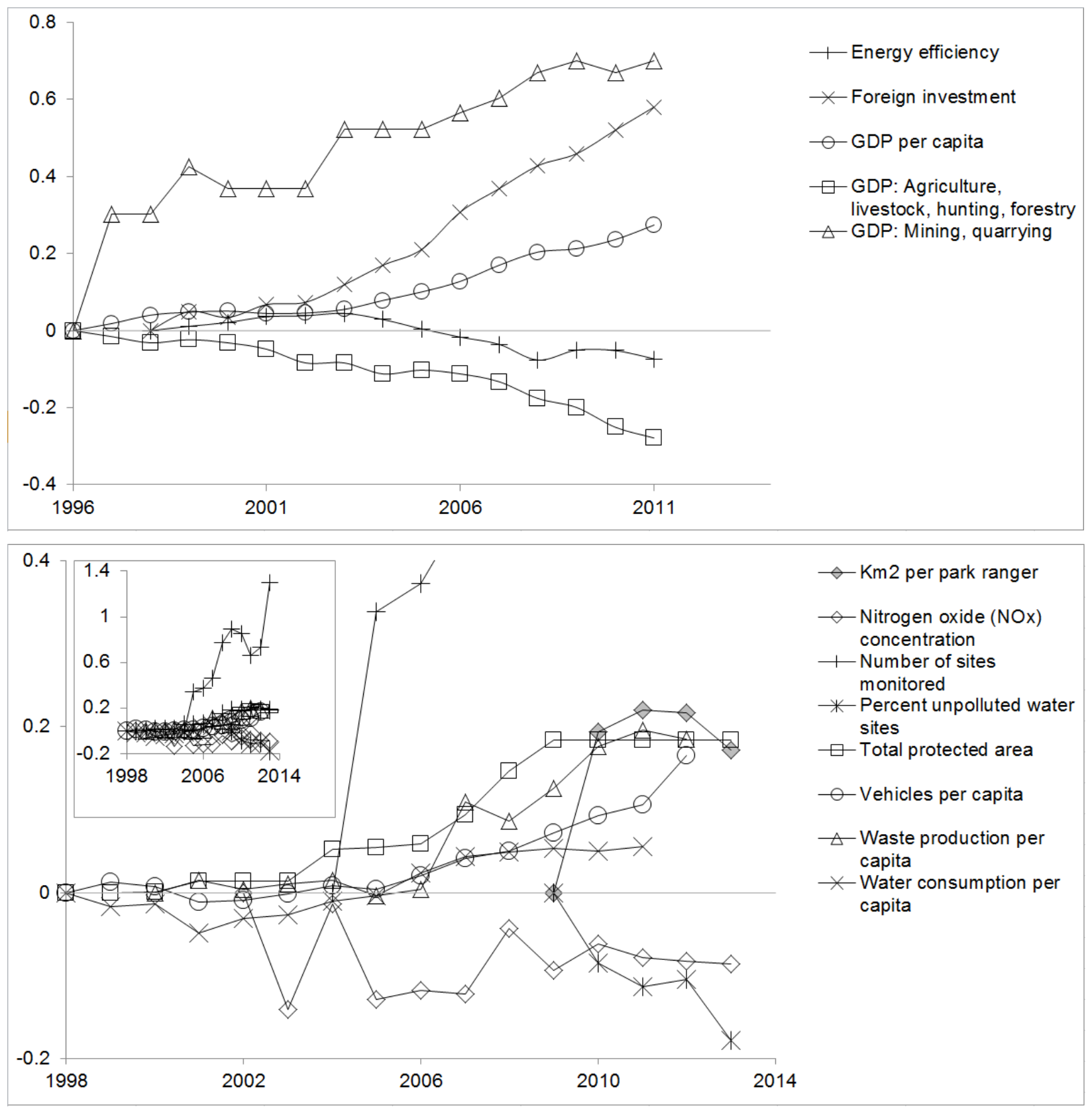


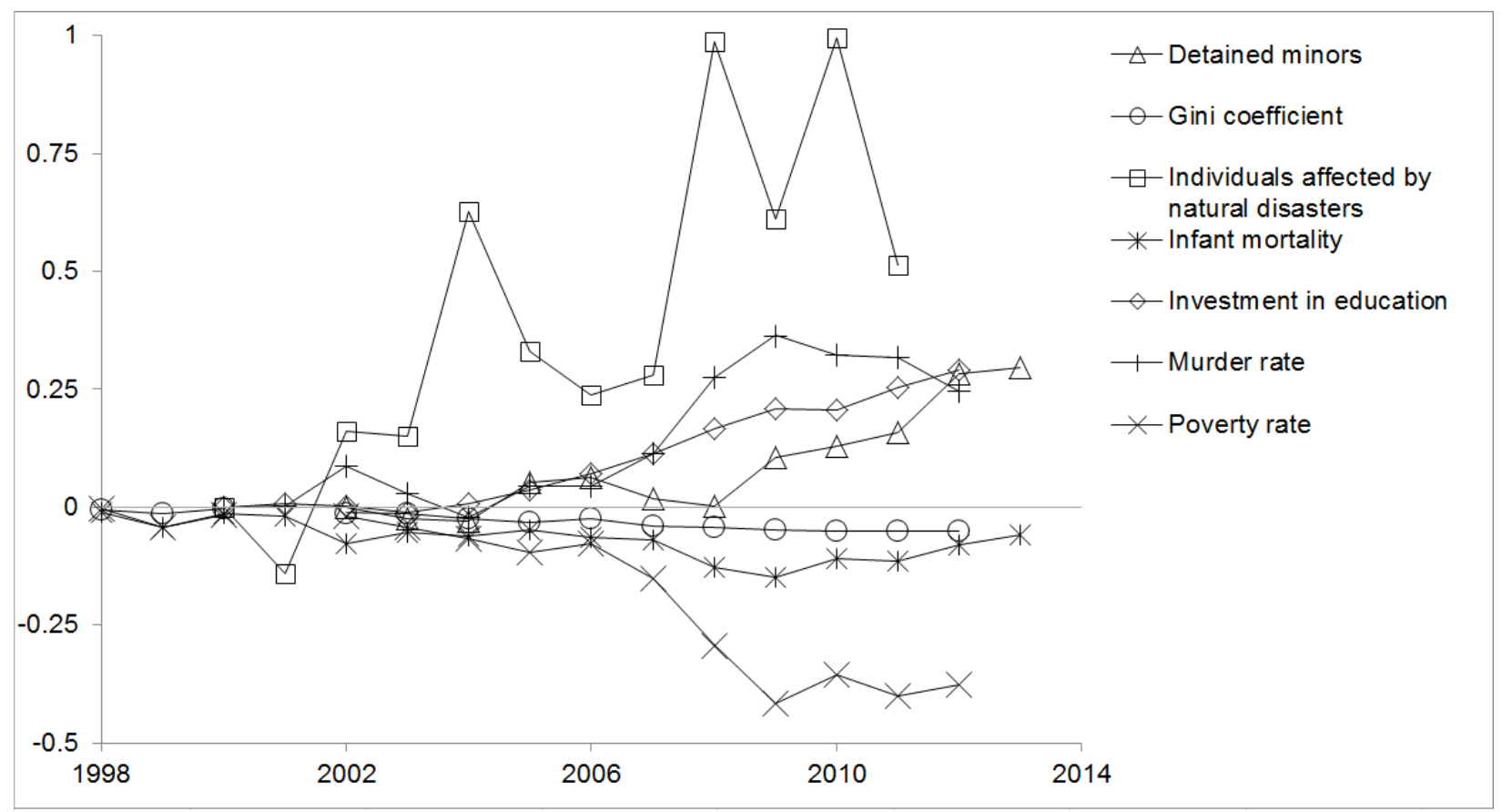




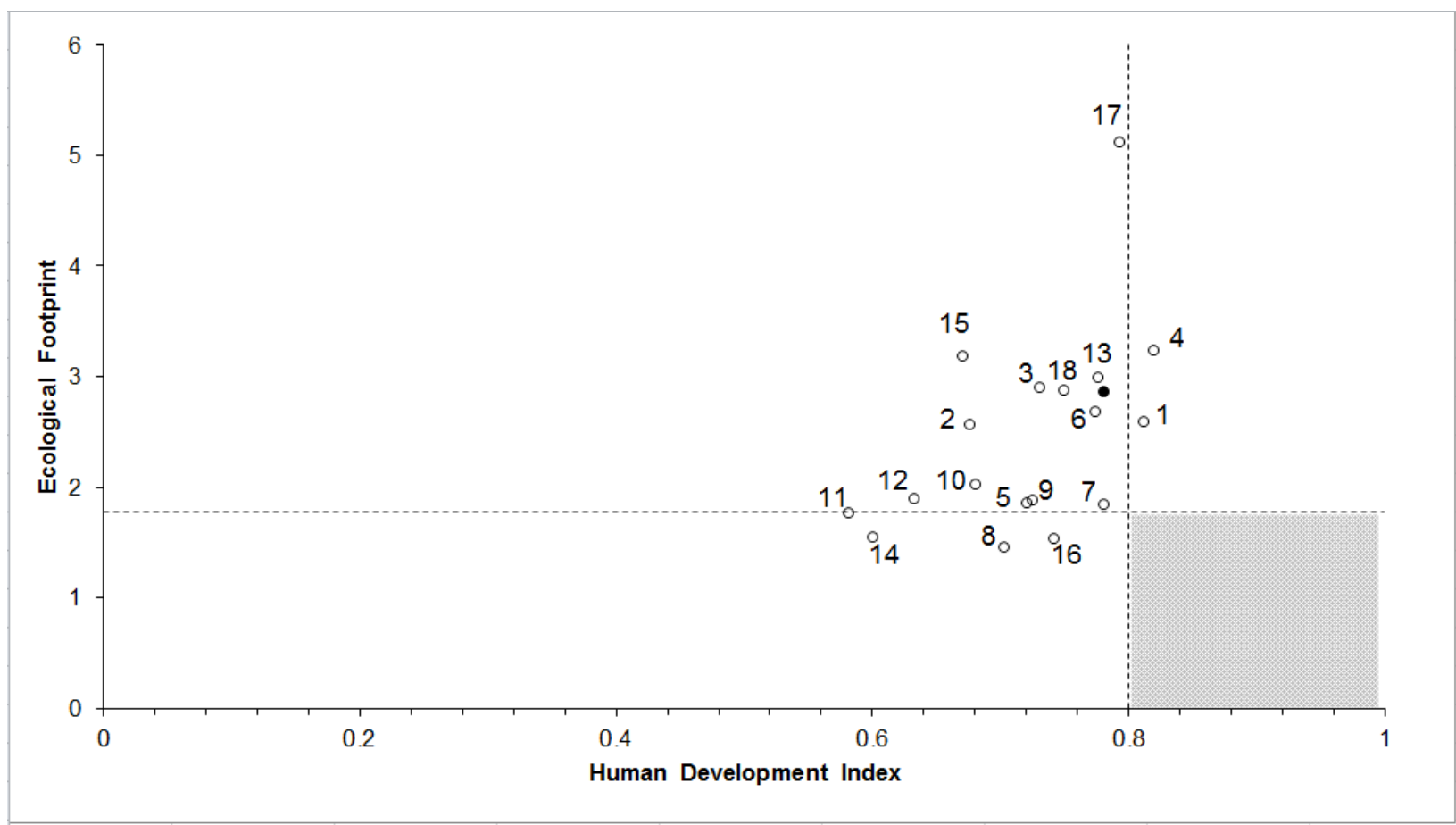

